\title{
OKUN'S LAW AND ASSESSMENT OF STIMULUS TO THE ECONOMY OF BOSNIA AND HERZEGOVINA
}

\begin{abstract}
The effects of coronavirus pandemics are omnipresent in the national economy of Bosnia and Herzegovina. Output and unemployment are probably the most important variables for measuring the negative effects of the pandemics from a macroeconomic perspective. Different organizations, both national and international, have announced their autumn and winter prognoses of these variables for 2020. None of them are optimistic. The Bosnian economy is in the worst situation in the last two decades.

International Monetary Fund approved US\$ 361 million in urgent support to B\&H in 2020 to alleviate the COVID-19 negative economic consequences. This paper aims to investigate the potential economic impact of that financial support with the application of simple arithmetic. In the paper, Okun's law is used as a methodological framework to assessing the effects of the IMF's rapid financial instrument. The relationship between the real economic growth and change in the unemployment rate is estimated for the $B \& H$ economy.

Findings of the paper show that the IMF financial support effect amounts to about $3.7 \%$ of GDP in B\&H. Effects on the unemployment rate are estimated to 2.3 percentage points less than what it would otherwise have been. Since the early estimations of the GDP in B\&H indicated a deep recession in 2020 this financial support proved to be an insufficient stimulus to the B\&H economy. Decision-makers in the country should be aware of their responsibility for providing larger stimulus packages to avoid bad economic and social outcomes soon.
\end{abstract}

Keywords: Okun's law, economic growth, unemployment rate, IMF financial support, Bosnia and Herzegovina

JEL: $E 65$

1 Associate professor, University of Zenica, Faculty of Economics, contact: jasmin.halebic@unze.ba 


\section{INTRODUCTION}

Macroeconomics is an area of economics with lots of controversies and ongoing debates. Advocates of the same ideas come together and form the school of economic thought. In that way, numerous schools appeared in economics. However, there are some points of consensus among macroeconomists, and Okun's Law is one of those themes that is almost unanimously supported representing a strong empirical relationship (Blinder, 1997). According to Okun's Law, there is a negative relationship between two very important macroeconomic variables, unemployment, and output. The intuition behind this relationship is that growth of output can lead to unemployment decrease. Simply, additional labor is necessary for the production of more goods and services in an economy. Thus, all programs aimed at the reduction of unemployment should be based on boosting output. Put differently, Okun's Law explores how much of a country's output may be expected to be lost if unemployment starts to go beyond the bounds of its natural level. Okun's Law is now built-in forecasters believe even in times of economic downturns.

The economy is a complex interconnected system of markets and Okun's Law describes the relationship between two markets: labour and goods markets. Generally, policymakers should be interested in the responsiveness of labour markets (measured in unemployment rates) to economic policy measures holding inflation to acceptable limits.

Pandemics of the coronavirus caused tremendous negative consequences globally. In terms of economics, those negative consequences are measured in the fall of output. The looming recession in 2020 might be continued with hard depression in those countries that do not design and implement necessary measures to support the economy. Any delay and postponement in the implementation of those economic measures will lead to extended economic hardship. The economy of B\&H shrunk in 2020 experiencing the most severe economic downturn in the post-war period. In 2020 IMF approved US\$ 361 million as emergency support expecting an economic decline of $-5 \%$ and gradual recovery in 2021. Recent projection of real GDP reveals an even worse scenario of plummeting off the economy by $-5.5 \%$ GDP and introducing a substantial short- to mid-term severe economic impact.

This paper is motivated by the fact of an almost unexplored inverse relationship between output and unemployment in the economy of B\&H. Arithmetic of the Okun's Law serves as a basis for simple assessment of effects of the IMF financial assistance to B\&H. Analysis of Okun's Law provides a starting point for policymakers in $\mathrm{B} \& \mathrm{H}$ and their attempt to create sound economic policy based on specific responsiveness of state labour market to national output change.

The paper aims to estimate a simple relationship between output and unemployment 
and based on the results to make some recommendations for economic policy in the $\mathrm{B} \& \mathrm{H}$ economy. The paper hypothesis that will be tested is that the association between output and unemployment in the form of Okun's Law gives valuable insights into the B\&H economy. The results obtained provide further support for this hypothesis in the case of the B\&H economy for the analysed period.

The paper is organized as follows. Section 2 offers a literature review of Okun's Law. Section 3 introduces the research method and main findings of the paper which are discussed in more details in Section 4. In Section 5 we give some concluding remarks.

\section{Literature review}

The relationship between unemployment and output was quantified in 1962 by A. Okun for the USA economy. He reported that "for each extra one per cent of GNP, unemployment is 0.3 points lower" (Okun, 1962). He examined quarterly data of the USA economy for the period 1948Q2 to 1960Q4. Similar results have been obtained in other researches of recent formulations of Okun's Law with extended periods to cover 1949Q1-2015Q4, although the correlation coefficient in absolute terms increased from 0.332 to 0.684 (Canarella \& Miller, 2017). Economists confirmed the existence of Okun's Law in numerous countries observing different values of the Okun coefficient. In most industrial countries the Okun coefficient is higher than in the US (Neely, 2010). A Higher Okun coefficient indicates less variability of unemployment rate associated with a certain change in GDP. Countries with rigid labour market provisions (stronger trade unions, formal restrictions in hiring and releasing employees) tend to have higher Okun coefficients. This empirical regularity was investigated and confirmed in many instances such as G7 countries (Moosa, 1997), Latin American countries (Pizzo, 2020), OECD and non-OECD countries (Huang \& Yeh, 2013), advanced and developing countries (Ball, et al., 2019), etc.

There have been attempts to use Okun's Law study at the sub-national level in countries such as France (Binet \& Facchini, 2013) and the USA (Prieto, et al., 2018). Okun coefficient estimated in those studies shows that its value is quite close across sub-national levels. However, some differences in the Okun coefficient across sub-national levels can be explained by distinct and dissimilar industrial structures. In other studies factors such as higher education levels of population, rate of unionization in the labour market and share of non-manufacturing employment found to be of decisive importance in the determination of the Okun coefficient at sub-national levels (Guisingera, et al., 2018). 
In the relevant literature, there is also empirical evidence on youth unemployment showing more reaction to changes in economic growth in comparison to older population cohorts. Researchers in those studies confirmed higher unemployment rates' responsiveness of young males and females to changes in output than that of total unemployment of the same gender (Butkus \& Seputiene, 2019). This finding of age and gender sensitivity in value of Okun coefficient are recommended to be considered in economic policy formulations aimed at reducing the unemployment rate (Kim \& Park, 2018).

Some researchers also investigated changes in the Okun coefficient in times of recession and expansion establishing a sort of asymmetry in the value of the coefficient. In times of recessions, the Okun coefficient tends to be higher than in periods of economic expansion due to decisions of firm owners to escape any hesitation in the layoff of workers during a recession. On the other side, in times of economic expansion firm owners prefer to increase overtime working hours than to increase employment (Lim, et al., 2018). A country-level analysis for EU28 also indicates similar results, higher Okun coefficient values have been observed in the post-crisis period of 20082014 than in pre crises period of 2001-2007 in EU28 countries (Novak \& Darmo, 2019).

In the literature several factors can be recognized as influential ones to the Okun coefficient:

Shadow economy. In countries with a huge informal economy, the relationship between the unemployment rate and output growth is far from clear. Evidence shows a smaller correlation coefficient between the labour market and change in output growth in those countries with substantial shadow economies (Singh, et al., 2012).

Labour and business regulations. This factor refers to the reaction of labour markets concerning regulations (rules of the game) existing in specific product and labour markets. If regulations regarding hiring and releasing of employees, for instance, are strict then, consequently, changes in unemployment will be less responsive to changes in output. Job security provisions make hiring and laying off workers more difficult for firms and they reluctantly show any sensitivity to output changes such as short-term recessions and expansions (Kaufman, 1988). Similar logic exists behind other sorts of labour and market regulations. ${ }^{2}$

2 Besides hiring and firing provisions there are other aspects of labour and product market regulations such as, unionisation of labour market and centralized collective bargaining, rigidity of working hours, costs related to worker dismissal, etc., or those that can be understood as business regulations manifested in all kinds of costs: bureaucracy costs, start-up costs, bribes and corruption, etc. 
Structure of the economy. Countries with the larger agricultural sector are typically more resistant, in terms of unemployment, to output fluctuations. On the other side, a relationship described by Okun's Law is more powerful in countries with salient industry sectors (Farole, et al., 2017).

Service sector contribution to GDP. There are findings in the empirical research literature that indicate higher responsiveness of the unemployment rate to changes in growth in output in countries with larger service sectors in the economy (Crivelli, et al., 2012; Ball, et al., 2019).

Skill mismatch index. When skill mismatch is defined as the difference between demand and supply in skills, that is those embodied in existing jobs (demand) and those in the overall labour force (supply), then a higher skill gap can be linked to a meagre association between changes in unemployment and output (Ball, et al., 2019).

Poverty rate. This aspect of a country may have been an important factor in the relationship between the unemployment rate and output. In the literature, a high poverty rate may be associated with less responding of the unemployment rate to output changes (An, et al., 2017). Hence, in poor countries, low values of the Okun coefficient may be expected.

Quality of institutions. Okun coefficient value can also be influenced by institutions since institutions are generally seen as a strong factor related to economic outcomes such as output and unemployment (Halebic, 2011).

Table 1: Okun coefficient: Explanatory variables and expected relationships

\begin{tabular}{|l|l|}
\hline \multicolumn{1}{|c|}{ Explanatory variables } & \multicolumn{1}{c|}{ Expected relationship } \\
\hline Size of shadow economy & Negative \\
\hline Labour market regulations (labour market flexibility) & Positive \\
\hline Business regulation (product market flexibility) & Positive \\
\hline Structure of the economy & Positive / Negative \\
\hline Service sector contribution to GDP & Negative \\
\hline Skill mismatch index & Negative \\
\hline Poverty rate & Negative \\
\hline Quality of institutions (rule of law) & Positive \\
\hline
\end{tabular}

Source: Author's creation based on Pizzo, 2020 and Ball, 2019.

\section{Research method and data}

For analysis of the relationship that is represented by Okun's Law two variables are needed: unemployment and output growth. In this paper we refer to the period from 2009 to 2019, containing 11 intervals. Variables are described in the following table. 
Table 2: Variables for Okun's Law calculation

\begin{tabular}{|l|l|l|l|}
\hline \multicolumn{1}{|c|}{ Variable } & \multicolumn{1}{c|}{ Description } & \multicolumn{1}{c|}{ Notification } & \multicolumn{1}{c|}{ Source } \\
\hline GDP & Change in real GDP (\%) & Y & $\begin{array}{l}\text { B\&H Agency for } \\
\text { Statistics }\end{array}$ \\
\hline Unemployment rate & Change in unemployment rate (\%) & $\mathrm{u}$ & \\
\hline
\end{tabular}

Source: Author's creation.

A graphic presentation of two variables related to Okun's Law in B\&H is given in the next Figure. In the last few years starting from 2015 relationship between output growth and unemployment is quite clear, output growth is linked to a decline in unemployment. In the first part of the period, the relationship is indistinctive since the period begins with output growth and an increase in unemployment. In the years that follow up to 2015, the output varies, rising in some years and falling in others while the unemployment is pretty much stable.

Figure 1: Unemployment rate and output growth in B\&H, 2009-2019

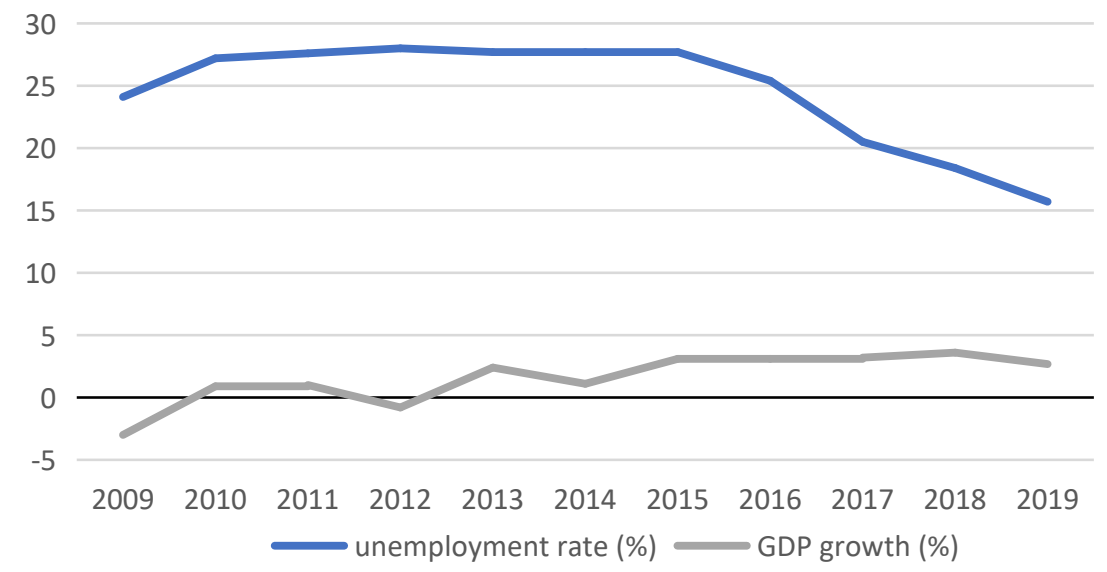

Source: Author's creation.

\subsection{Estimation of Okun's Law in B\&H economy}

Originally, Okun's Law has two versions: (i) the difference version, where Okun's Law captures changes in unemployment and GDP; and (ii) the gap version, in which growth in output is measured as a gap between potential output and actual output (Knotek, 2007). The Law usually takes the following form (Ball, et al., 2015):

$$
u_{t}-u_{t}^{*}=\beta\left(y_{t}-y_{t}^{*}\right)+\varepsilon_{t}, \quad \beta<0
$$

where: $u$ and $y$ stand for the unemployment rate and the log output, respectively; and mark * designates trend values. Error term, $\varepsilon$, represents all factors that can move the entire relationship of output-unemployment such as an unexpected shift in productivity or labour force participation (Ball, et al., 2019). In this paper, we restrain 
from discussions of some authors who question linearity in the above equation. With non-linearity assumption in Okun's Law equation “... effectiveness (and required 'size') of stabilization policy on the real economy would depend in which 'regime' Okun's relationship then lies" (Christopoulos, et al., 2019).

In this paper, we follow the approach from Mankiw (2019) and use a scatterplot tool to illustrate Okun's Law. Each dot in the scatterplot refers to the observed change in the unemployment rate and the growth rate in real GDP, in a particular year. In the horizontal axis of the scatterplot, we put the percentage change in GDP in B\&H. In the vertical axis, we put the change in the unemployment rate ${ }^{3}$ in $\mathrm{B} \& \mathrm{H}$ calculated from the previous year.

Figure 2: Okun's Law in B\&H economy, 2009-2019

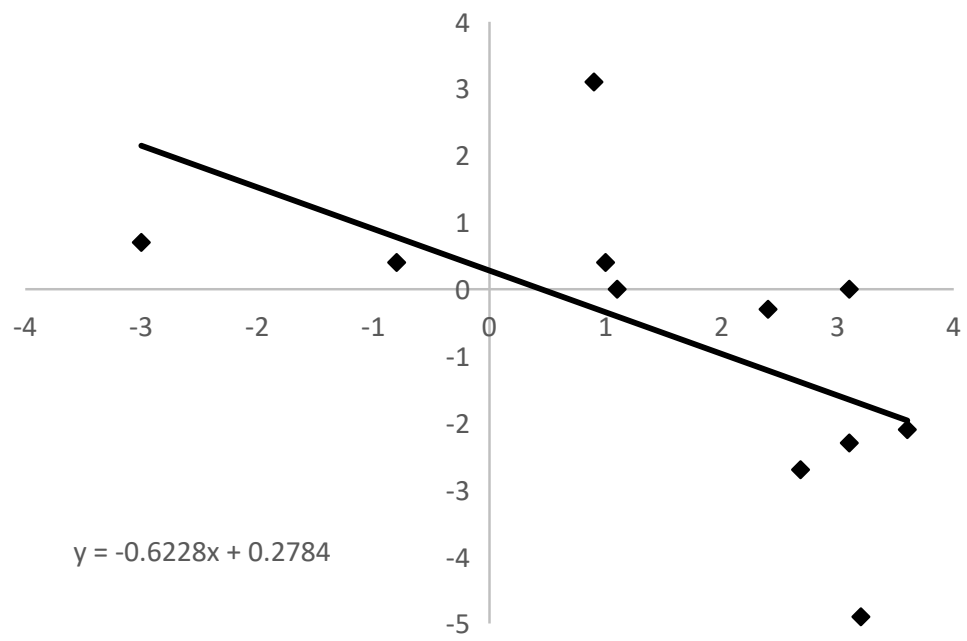

Source: Author's creation.

From the scatterplot figure we observe that regression line is downward sloping which suggests that there is negative relationship between output growth and unemployment. The figure shows that there has been marked negative association between changes in unemployment and output over time. Estimated equation of Okun's Law is:

$$
\Delta u_{t}=0.2784-0.6228 y_{t}
$$

3 The Unemployment rate is taken from Labour Force Survey which uses The International Labour Organization (ILO) definition of unemployment since the official unemployment rate and the ILO rate in case of $\mathrm{B} \& \mathrm{H}$ differ substantially. 
From equation (1) several findings follow (Blanchard, et al., 2017):

- Negative relationship between output growth and unemployment rate means that higher output is associated with a decrease in unemployment. The slope of the regression line is - 0.62 suggesting that economic growth of $1 \%$ is, on average, associated with a decline in the unemployment rate for 0.62 percentage points. Additionally, a negative sign of the slope confirms economic theory explanation that periods of the economic expansion lead to decreasing unemployment and vice versa.

- Downward sloping regression line crosses the horizontal axis of the scatterplot at the point where the unemployment rate change is zero and output growth is approximated to $0.45 \%$. This value has an economic interpretation. Low economic growth, i.e., $\Delta \mathrm{GDP} \approx 0.45 \%$, will not cause any change in the unemployment rate in $\mathrm{B} \& \mathrm{H}$. If policymakers want to combat the high unemployment rate in the B\&H economy then they must devise economic policies that result in substantial economic growth rates, higher than $0.45 \%$.

In April 2020 the IMF Executive Board approved US\$ 361 million $^{4}$ to B\&H as emergency assistance with a purpose to alleviate urgent balance-of-payments $(\mathrm{BoP})$ need. $\mathrm{B} \& \mathrm{H}$ is faced with chronic BoP problems in the long-run. The average current account deficit of BoP is about BAM -1,800 million or $-6.7 \%$ of GDP in the period 20072019. The net international investment position of $B \& H$ in the same period is also negative. $\mathrm{B} \& \mathrm{H}$ is in the status of the net debtor to the rest of the world. That status brings a financial vulnerability to the $\mathrm{B} \& \mathrm{H}$ economy and it might undermine foreign investors' confidence in a time of financial or economic shocks (Halebic, 2021). IMF financial support of US\$ 361 million is about $1.76 \%$ of 2019 GDP in B\&H.

\subsection{Stimulus arithmetic of IMF financial support}

According to stimulus arithmetic in Krugman (2020), Okun's Law can be used as a starting point for making simple assessments of impact. Interpretation of the Okun's Law coefficient states that one has to raise real GDP by the value of that coefficient "...from what it would otherwise have been to reduce the unemployment rate 1 percentage point from what it would otherwise have been" (Krugman, 2020, p. 117). It means that the GDP of the B\&H economy in 2019 of US\$ 20,465 million should be raised for the amount of GDP growth times the Okun's Law coefficient (in percent) to calculate potential effects on unemployment (in percentage points).

$4 € 333$ million or SDR265.2 million, that is equal to its $100 \%$ SDR quota. 
In the next step of analysis, we use a multiplier for spending in order to estimate the overall effect of IMF stimulus on raising GDP in B\&H. If we assume a multiplier of 2 then IMF emergency support of US\$ 361 million in 2020 can be estimated to US\$ 762 million or $3.7 \%$ of GDP 2019. Having in mind equation (1) we can calculate the whole effect of the stimulus on unemployment:

$$
u_{t}=-0.6228 \cdot 3.7 \rightarrow u_{t}=-2.30
$$

Thus, IMF financial support implemented in B\&H during 2020, with the assumption of the multiplier of spending being 2 , might be associated with the reduction of the unemployment rate of -2.3 percentage points from what it would have been without this support. According to the first results ${ }^{5}$ from the labour market in $\mathrm{B} \& \mathrm{H}$, the unemployment rate is estimated to $16.4 \%$. Therefore, without IMF financial support the unemployment rate in 2020 would be, ceteris paribus, $18.7 \%$.

\section{Discussion}

In the last five years, 2015-2019, the B\&H economy experienced significant economic growth of more than a cumulative $17 \%$ or $3.4 \%$, on average. This positive economic situation was accompanied by a reduction in the unemployment rate from $27.7 \%$ in 2015 to $15.7 \%$ in 2019 . The annual unemployment rate decline was near $2.4 \%$. In 2020, after the outbreak of pandemics of the coronavirus the things have deteriorated. The economic lockdown was imposed lasting for 2.5 months and other measures designated for human health protection were introduced. At the end of 2020 , the last forecasts of IMF announce a gloomy scenario of a $-5.5 \%$ fall in GDP. ${ }^{6}$

In the current economic system setting in $\mathrm{B} \& \mathrm{H}$ conducting an effective economic policy is faced with huge obstacles. The monetary policy framework gives the Central bank of B\&H only one instrument of monetary policy, that of required reserve rate determination. This instrument of monetary policy proves to be mostly ineffective since commercial banks in $\mathrm{B} \& \mathrm{H}$ hold deposits over the required reserve rate limit of $10 \%$. The fiscal policy framework is decentralized between state and entity and lower levels of government. This framework is especially over-institutionalized in the entity of FB\&H. As an example, illustrating this complexity we can mention the IMF emergency support distribution in B\&H. It took about 3.5 months from allocation of financial support to the state level in April 2020, to its final distribution to cantons in mid of August 2020. In this context, IMF emergency support appeared to be ill-managed in terms of timely distribution of the support to the end-users.

5 The average value of two 3-month periods (Agency for Statistics of B\&H).

6 https://www.imf.org/en/News/Articles/2020/12/18/pr20381-bosnia-and-herzegovina-imf-staff-concludes-visit-to-bosnia-and-herzegovina (accessed: 25.12.2012). 
Usage of other instruments of fiscal policy on the state level has been heavily burdened with political gridlock over the whole of 2020 and the beginning of 2021. Lower government levels: entity, cantons, cities and municipalities in B\&H suffered public revenues reduction since coronavirus pandemics also caused a sharp fall in economic activity, especially in sectors of tourism and transportation resulting in rising unemployment. Those lower levels designed and implemented several economic measures mostly through "corona pieces of legislation." Effects of these measures remain to be assessed in the future.

Implementation of IMF emergency support, when analysed in simple stimulus arithmetic and with assumption of the size of spending multiplier of 2 , shows that possible impact of this support can be estimated to about -2.3 percentage points decline of unemployment rate from the level that would otherwise have been. Current disputes on the political scene over the next, even larger, IMF financial support, that have been witnessed during negotiations, might cause further delay in implementation of necessary measures to combating COVID-19 pandemics and defer in giving impetus to fiscal plans in 2021. Alternatives to IMF financial support in 2021 do not look very promising, since monetary policy has been proved largely ineffective and fiscal policy takes too much time for its enacting and implementation. If the current economic downturn is forecasted to last for more than one year then fiscal incentives are also recommended to be used for stimulating a deeply affected economy.

In some countries, similar studies have been conducted at subnational levels too. This sort of analysis at sub-national levels in B\&H would also be potentially interesting and useful but it must be postponed until data on the output and the unemployment changes become available at those levels.

\section{CONCLUSION}

Long-term growth in GDP, as one of the primary macroeconomic goals, is influenced by factors such as technological progress. Economic growth in the long-term is not connected with similar trends in the labour market such as a change in the unemployment rate. The research problem that was addressed in the paper is how to assess macroeconomic consequences of the pandemics COVID-19 in B\&H together with IMF financial support and what perspectives are available before economic decision-makers in the future. In the paper, we presented an analysis of changes in GDP. In the analysis relationship between GDP growth and unemployment rate is examined in B\&H in the period 2009-2019. Returning to the hypothesis posed at the beginning of this paper, it is now safe to state that there is a relatively strong and negative correlation between changes in GDP and the unemployment rate in the B\&H economy. 
Based on the findings of this paper it can be recommended that it is very important for $\mathrm{B} \& \mathrm{H}$ to decisively bolster output growth aiming at high economic growth rates in the long-run in to substantially reduce the relatively high unemployment rate. With sluggish economic growth, as in the period 2009-2014, the unemployment rate remains almost untouched. Only with robust economic growth, as in the period 2015-2019, it is possible to significantly bring down the unemployment rate. In that way, other problems in the country that are connected with high unemployment could be mitigated. Among them is the emigration of the working age population, especially young and skilled persons.

Being limited in conducting effective monetary policy and with very complex fiscal policy responsiveness to economic shocks, B\&H should use financial resources available from international organizations, such as IMF, and direct them to sectors of the economy, health and social security. B\&H lacks the necessary resources for massive stimulus measures of its own that can be compared to the size of financial resources provided by developed countries for their economies. The political backlash could be one of the most serious impediments to the realization of $\mathrm{B} \& \mathrm{H}$ growth potential to be beneficial for improvements in macroeconomic management, fully integration of the economy and preserving of its financial stability.

\section{REFERENCES}

1. An, Z., Ghazi, T., Prieto, N. \& Ibourk, A., 2017. Growth and Jobs in Developing Economies: Trends and Cycles. IMF Working Paper, 17(257).

2. Ball, L., Furceri, D., Leigh, D. \& Prakash Loungani, P., 2019. Does One Law Fit All? Cross-Country Evidence on Okun's Law. Open Economies Review, Issue 30, pp. 841-874.

3. Ball, L., Jalles, J. \& Loungani, P., 2015. Do forecasters believe in Okun's Law? An assessment of unemployment and output forecasts. International Journal of Forecasting, Volume 31, pp. 176-184.

4. Binet, M. \& Facchini, F., 2013. Okun's law in the French regions: a cross-regional comparison. Economics Bulletin, 33(1), pp. 420-433.

5. Blanchard, O., Amighini, A. \& Giavazzi, F., 2017. Macroeconomics: a European Perspective. 3rd ed. Essex, England: Pearson Education Limited.

6. Blinder, A., 1997. Is There a Core of Practical Macroeconomics That We Should All Believe?. American Economic Review, 87(2), pp. 240-43.

7. Butkus, M. \& Seputiene, J., 2019. The Output Gap and Youth Unemployment: An Analysis Based on Okun's Law. Economies, 7(108).

8. Canarella, G. \& Miller, S., 2017. Did Okun's law die after the Great Recession?, Washington, DC: National Association for Business Economics. 
9. Christopoulos, D., P., M. \& Tzavalis, E., 2019. Exploring Okun's law asymmetry: an endogenous threshold LSTR approach. ECB Working Paper Series, Volume 2345.

10. Crivelli, E., Furceri, D. \& Bernate-Toujas, J., 2012. Can Policies Affect Employment Intensity of Growth? A Cross-Country Analysis. IMF Working Paper, 12(218).

11. Farole, T., Ferro, E. \& Michel Gutierrez, V., 2017. Job Creation in the Private Sector: An Exploratory Assessment of Patterns and Determinants at the Macro, Sector, and Firm Levels. Jobs Working Paper, Volume 5.

12. Guisingera, A., Hernandez-Murillo, R., Owyang, M. \& Sinclair, T., 2018. A state-level analysis of Okun's law. Regional Science and Urban Economics, Volume 68, pp. 239-248.

13. Halebic, J., 2011. Role and significance of economic institutions in economic development of Bosnia and Herzegovina. Zenica: University in Zenica.

14. Halebic, J., 2021. Macroeconomics: good pages. Sarajevo: Economic institute Sarajevo.

15. Huang, H. \& Yeh, C., 2013. Okun's Law in Panels of Countries and States. Applied Economics, 45(2), pp. 191-199.

16. Kaufman, R., 1988. An International Comparison of Okun's Laws'. Journal of Comparative Economics, Volume 12, pp. 182-203.

17. Kim, M. \& Park, S., 2018. Do gender and age impact the time-varying Okun's law? Evidence from South Korea. Pacific Economic Review, pp. 1-14.

18. Knotek, E., 2007. How Useful Is Okun's Law?. Federal Reserve Bank of Kansas City, Economic Review, Issue Fourth Quarter, pp. 73-103.

19. Krugman, P., 2020. Arguing with Zombies: Economics, Politics, and the Fight for a Better Future. New York: W.W. Norton \& Company.

20. Lim, G., Dixon, R. \& van Ours, J., 2018. Beyond Okun's Law: Output Growth and Labor Market Flows. Tinbergen Institute Discussion Paper, 97(V).

21. Moosa, I., 1997. A Cross-Country Comparison of Okun's Coefficient. Journal of Comparative Economics, Volume 24, pp. 335-356.

22. Neely, C., 2010. Okun's Law: Output and Unemployment. Economic Synopses, Issue 4.

23. Novak, M. \& Darmo, L., 2019. Okun'S Law over the business cycle: does it change in the EU countries after the financial crisis?. Prague Economic Papers, 28(2), pp. 235-254.

24. Okun, A., 1962. Potential GNP: Its Measurement and Significance. In: Proceedings of the Business and Economic Statistics Section of the American Statistical Association. Alexandria: American Statistical Association, pp. 89-104. 
25. Pizzo, A., 2020. Literature Review of Empirical Studies on Okun's Law in Latin America and the Caribbean. Employment Working Paper, Issue 252.

26. Prieto, N., Loungani, P. \& Mishra, S., 2018. What Lies beneath? A Sub-National Look at Okun's Law in the United States. Open Economic Review.

27. Singh, A., Jain-Chandra, S. \& Mohommad, A., 2012. Inclusive Growth, Institutions, and the Underground Economy. IMF Working Paper, 12(47).

Jasmin Halebic

\section{OKUNOV ZAKON I OCJENA STIMULANSA ZA EKONOMIJU BOSNE I HERCEGOVINE}

\section{SAŽETAK}

Efekti pandemije korona virusa su sveprisutni u ekonomiji Bosne i Hercegovine. Proizvodnja i nezaposlenost su vjerovatno najvažnije varijable iz makroekonomske perspektive za mjerenje negativnih efekata pandemije. Različite organizacije, državne i međunarodne, su objavile svoje jesenje i zimske prognoze tih varijabli za 2020. godinu. Nijedna od njih nije optimistična. Ekonomija u BiH se nalazi u najtežoj situaciji u posljednja dva desetljeća.

Međunarodni monetarni fond je odobrio hitnu podršku od 361 mil USD za BiH u 2020. g. radi ublažavanja negativnih ekonomskih posljedica COVID-19. Cilj rada jest istražiti potencijalni ekonomski utjecaj te finansijske podrške primjenom jednostavne aritmetike. U radu se Okunov zakon koristi kao metodološki okvir za ocjenu efekata MMF-ovog brzog finansijskog instrumenta. Estimirana je povezanost između realnog ekonomskog rasta i promjena stope nezaposlenosti u BiH.

Nalazi rada pokazuju da finansijska podrška MMF-a čini oko 3.7\% BDP-a u BiH. Efekti na stopu nezaposlenosti su procijenjeni na 2.3 procentna boda manje od nivoa stope nezaposlenosti koja bi, u protivnom, nastala. Budući da rane estimacije BDP-a u BiH ukazuju na duboku recesiju u 2020. g. ova finansijska podrška se pokazala nedovoljnim stimulansom za ekonomiju BiH. Donositelji odluka u zemlji trebaju biti svjesni svoje odgovornosti za osiguranje većih stimulansa kako bi se izbjegli negativni ekonomski i socijalni ishodi u bliskoj budućnosti.

Ključne riječi: Okunov zakon, ekonomski rast, stopa nezaposlenosti, MMF finansijska podrška, Bosna i Hercegovina 